\title{
أنتثامبية العدد
}

يسرنا أن نضع بين يدي الباحثين والقراء العرب العدد الثاني من المجلة العلمية لكلية

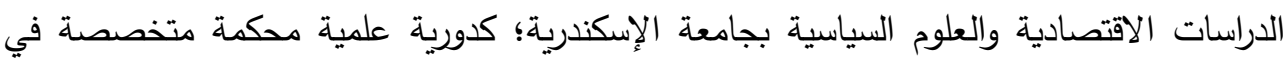

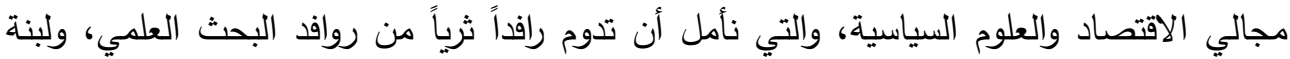

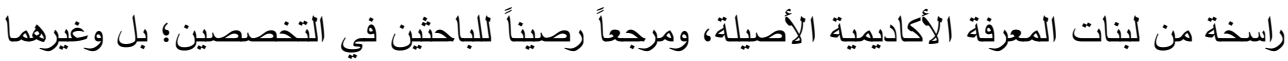
من مجالات العلوم الاجتماعية والإنسانية.

ويشتمل هذا العدد الثاني من أعداد المجلة على ست دراسات هامة ومتتوعة؛ تتثل أولاها في دراسة تقويمية للنظرية الواقعية كإحدى النظريات الرئيسية في تحليل العلاقات الدولية، وهي

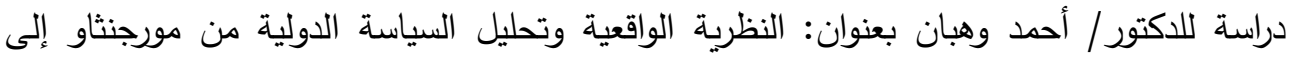

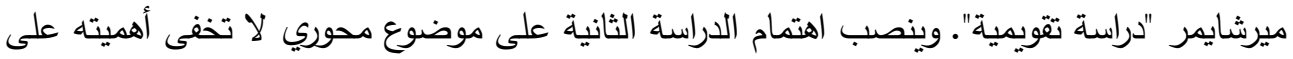

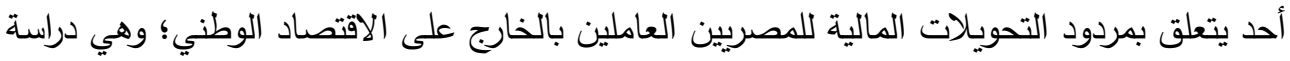
للدكتور/ علي عبد الوهاب نجا بعنوان: العلاقة بين التحويلات المالية للعاملين بالخارج والتطور لهردين

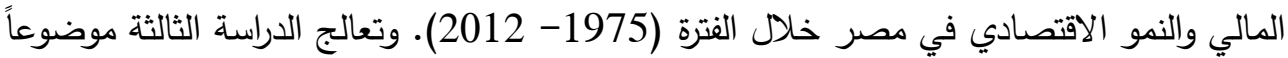
يتعلق الحركات الاحتجاجية كمحرك لتغيير النظام السياسي المصري (2004 - 2014)؛ وهي

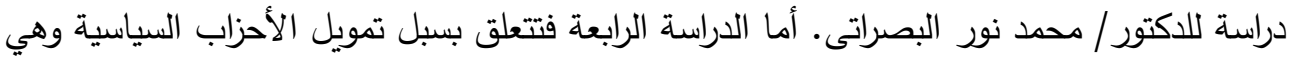

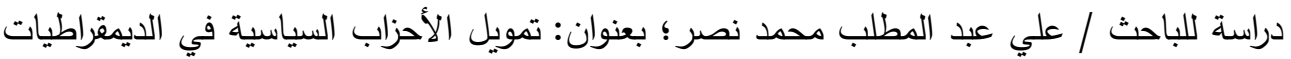

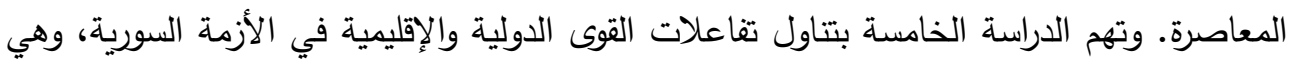
دراسة استشرافية للدكتور / محمود خليفة إبراهيم. وأخيراً تأتي الدراسة السادسة لتستعرض العاعلهات العوامل الكلية المحددة للاستثمار الأجنبي المباشر، وهي دراسة تطبيقية للدكتور / محمد سيد عابد يتتاول فيها للاقتصاد المصري خلال الفترة من (1980 - 2015).

وفي النهاية؛ فإننا إذ نضع هذا العدد بين يدي القارئ والباحث العربي نأمل أن يمثل إضافة حقيقية إلى بنيته المعرفية، كما نتطلع إلى تقديم المزيد كماً ونوعاً في ثنايا أعداد قادمة، والله من وراء القصد. رئيس التحرير 